\title{
IGSF8 Gene
}

National Cancer Institute

\section{Source}

National Cancer Institute. IGSF8 Gene. NCI Thesaurus. Code C74514.

This gene is involved in cellular proliferation and motility. 